Anna Matuchniak-Krasuska

\title{
Między groteską a realizmem O estetycznej stylizacji plakatów Plakat jako przedmiot analiz socjologii sztuki
}

\section{Socjologia dzieła sztuki}

Socjologia sztuki jest subdyscypliną socjologii kultury, a tym samym częścią socjologii. Swój przedmiot badań - sztukę - dzieli z wieloma innymi dziedzinami nauki, zwłaszcza zaś z estetyka, filozofia, psychologią i historią sztuki, co przesądza o jej „mediacyjnym” charakterze (Zolberg 1982). Badanie społecznego funkcjonowania dzieł sztuki obejmuje kwestie estetyczne oraz socjologiczne, a tym samym wymaga powiązania analiz autotelicznych i heterotelicznych funkcji sztuki. Jak pisze A. Kłoskowska:

Sztuka jest kategorią kultury symbolicznej zdolną do pełnienia funkcji estetycznej. Procesy semiotyczne przerastają $\mathrm{w}$ przypadku sztuki potrzeby instrumentalnego komunikowania, stając się celem samym w sobie, a więc przybierając charakter autoteliczny (Kłoskowska 1983).

Obrona tezy o autonomii sztuki jako kategorii kultury symbolicznej nie wyklucza wcale badania złożonych relacji sztuki i społeczeństwa. Sztuka jest wyrazem społeczeństwa, które ją wydało, ale równocześnie jest związana ze społeczeństwem, które ją przyjęło, co podkreślali m. in. H. Taine i J. P. Sartre (Kalinowski 1973). Za podstawowe dla socjologii sztuki można zatem uznać orientację socjogenetyczna, analizującą zależność struktury dzieła sztuki od miejsca i epoki, w której powstało, oraz orientację funkcjonalną, zajmującą się procesem odbioru 
tak ukształtowanego dzieła przez publiczność, czyli zagadnieniami kulturalnego uczestnictwa. Wielu znakomitych badaczy uznało te kwestie za główne problemy socjologii sztuki. S. Ossowski, interesując się społeczną egzystencją dzieła sztuki, socjologiczną analizą objął przede wszystkim dzieło jako pewien wytwór życia społecznego oraz dzieło jako przedmiot reakcji emocjonalnych ukształtowanych pod wpływem środowiska (Ossowski 1966). P. Bourdieu dokonując analizy „pola dóbr symbolicznych”, wyodrębnił badania "pola nadawców” oraz „pola odbiorców" i charakteryzował społeczną rangę funkcjonujących przekazów (Bourdieu 1971).

P. Francastel podkreślał, że socjologiczne badanie środowisk twórców i odbiorców sztuki musi opierać się na pogłębionej analizie dzieł sztuki łączącej ich immanentne cechy i środki wyrazu z formami społecznego obiegu (Francastel 1964; 1970). Wyznaczając ramy socjologii sztuki, zaproponował jako jeden z sześciu kierunków badania ",socjologię dzieł”, zajmującą się zewnętrzną i wewnętrzną analizą przedmiotów artystycznych (Francastel 1964). Pierwsza z nich, polegająca na typologii dzieł sztuki na podstawie ich formy i funkcji, prowadzi do wyróżnienia subdyscyplin socjologii sztuki, takich jak socjologia malarstwa, socjologia literatury czy socjologia teatru. Natomiast druga - analiza wewnętrzna - ma na celu wyodrębnienie elementów spajających dzieło i decydujących o jego charakterze tematów, toposów, wątków. "Socjologia tematów” umożliwia przegląd historii sztuki pod kątem występowania i ujęcia zarówno obrazem, jak i słowem różnych klasycznych wątków, np. aktu, portretu, wizerunku Madonny. Analizę tematów artystycznych i dziedzin sztuki uzupełnia "socjologia środków wyrazu” zajmująca się konstytuującymi dzieło sztuki nośnikami materialnymi i ramami mentalnymi, takimi jak czas i przestrzeń. W książce pt. Twórczość malarska i społeczeństwo Pierre Francastel przedstawił przekształcenia czasoprzestrzeni średniowiecznej w dobie renesansu, a następnie jej rozbicie przez kubizm (Francastel 1973). Na podstawie pogłębionej analizy dzieł sztuki, przeprowadzonej na trzech wymienionych wyżej poziomach, może być prowadzone badanie środowisk twórców i publiczności, określane przez P. Francastela jako „socjologia grup i typologia kultur". Koncepcja znakomitego francuskiego socjologa konstruuje ramy teoretyczne tego opracowania.

Socjologiczne badania społecznego funkcjonowania sztuki, łączące kwestie strukturalno-estetyczne, socjogenetyczne i funkcjonalne, moga stanowić przyczynek do socjologii narodu, polityki czy studiów świadomości społecznej. 


\section{O specyfice plakatu}

Plakat jest dziedziną sztuk plastycznych o silnych funkcjach heterotelicznych. Wypada rozważyć, jak realizuje wszystkie wymienione przez A. Kłoskowską za R. Jakobsonem funkcje: konatywna, referencyjna, emotywna, estetyczną, metajęzykowa, fatyczną (Kłoskowska 1983). Atrakcyjna forma, mająca funkcje estetyczne, jest nośnikiem istotnych treści (to funkcja informacyjna, poznawcza). Niewątpliwie budzi (ma budzić) silne emocje odbiorcy, skłaniające go do działania. A zatem plakat stymuluje wszystkie elementy postawy - poznawczy, emocjonalny, behawioralny. Treść plakatu (element dzieła plastycznego) przekazuje odbiorcy informację, co nie oznacza, iż przekazuje prawdę, całą prawdę i tylko prawdę. $Z$ uwagi na pozaartystyczne (polityczne, ideologiczne, reklamowe) uwikłania plakatu, z całą pewnością przekazuje on informacje fragmentaryczne i tendencyjne. Artystyczna forma służy wyeksponowaniu tych tendencyjnych aspektów informacji, a tym samym stymuluje emocje odbiorcy. $Z$ psychoanalitycznego punktu widzenia forma dzieła sztuki „wabi i mami”. Teza ta znakomicie opisuje zamierzone działanie plakatu. Formalne opracowanie treści ma mieć działanie perswazyjne, performatywne, skłaniające do określonego działania, stymulujące behawioralny aspekt postawy. A zatem elementy przekazu plastycznego (treść, forma, emocje) wpływają na elementy postawy odbiorcy (poznawczy, emocjonalny i behawioralny). Różnego rodzaju plakatami, ich retoryką i interpretacją zajmowało się wielu autorów (Fresnault-Deruelle 1997).

Przedmiotem niniejszej analizy jest kilkaset plakatów, składających się na serie tematyczne uwikłane w kontekst narodowościowy i polityczny. Uwaga badacza zwrócona jest wyłącznie na postacie ukazane w tych dziełach sztuki i na konwencje ich przedstawienia - realizm czy groteskę. Pojawiają się pytania, która $\mathrm{z}$ wszechobecnych stylistyk plastycznych dominuje $\mathrm{w}$ tej serii plakatów politycznych i jakie są możliwe skutki dla ich społecznego oddziaływania. Analiza strukturalna dzieł sztuki nie jest specyficznym polem badań socjologicznych, jest jednak obszarem niezbędnym dla socjologa próbującego wyjaśnić kwestie socjogenetyczne dlaczego te plakaty mają taką konstrukcję formalną oraz funkcjonalna, z jakim odzewem społecznym mogły/mogą się spotkać. Czy analiza stylizacji plakatów wnosi coś do analizy ich funkcjonowania, którą zajęli się inni autorzy? 


\section{Realizm}

Realizm, groteska i abstrakcja to trzy główne typy sztuki istniejące już od jej zarania, to jest od paleolitu, widoczne w malarstwie jaskiniowym, a potem realizowane przez stulecia $w$ różnych miejscach i przejawiające się w kolejnych stylach artystycznych. Obecne są też w plakacie, ale $\mathrm{w}$ jakich proporcjach? Wydaje się, że plakat, $\mathrm{z}$ uwagi na funkcje informacyjne i perswazyjne, stosuje raczej sztukę przedstawiająca, czyli realistyczną i groteskową. Abstrakcja bywa wykorzystywana w plakacie rzadziej. Powszechnie znany jest co prawda znakomity plakat Lisieckiego Czerwonym klinem bij biatych, zamieszczony też $\mathrm{w}$ analizowanym zbiorze. Jest jedynym stricte abstrakcyjnym posterem $\mathrm{w}$ całej analizowanej kolekcji plakatów wojennych z różnych krajów.

Dominujący w sztuce realizm, uosabiany przez różne style, bywa rozmaicie definiowany. Naukowo użyteczna jest analiza S. Ossowskiego, który rozróżnił realizm treści, z uwagi na stosunek dzieła do rzeczywistości, oraz realizm formy, ze względu na sposób wykonania dzieła (Ossowski 1966). Realizm treści może oznaczać trzy różne rozwiązania: wierność indywidualną, realizm rodzajowy i realizm poszczególnych składników treści. Wierność indywidualna odnosi się do konkretnego desygnatu, realizuje ją portret, kronika czy powieść biograficzna. W plakacie występuje rzadko, na zdjęciach często, może zawsze (niewiedza odbiorcy o postaci przedstawionej na fotografii nie zmienia tej sytuacji). Na plakacie widniałaby powszechnie znana postać - bohater, przywódca. Znam plakat radziecki o metaforycznej konstrukcji - charakterystyczny profil Stalina tworzy też sierp, podkreślający krajobraz pożogi. $\mathrm{Na}$ wielu innych plakatach radzieckich, stosujących perspektywę hierarchiczna, identyfikowalna jest tylko "góra" - władza, przedstawiciele KC KPZR. Społeczeństwo, maszerujące $\mathrm{w}$ równych czworobokach do boju czy na defiladę, malowane jest $\mathrm{w}$ konwencji realizmu rodzajowego, a nawet groteski, z uwagi na niedostateczną determinację cech. Ludzie wyglądają niczym identyczne owady czy roboty, nie są przedstawieni dokładnie - tak jest np. na plakacie W. Jelkina z roku 1932.

W realizmie rodzajowym odtwarza się to, co typowe, ważne, a zatem jest to „kult przeciętności”. Realizm poszczególnych składników treści zastosowany został przez Michała Anioła. Malowidła Sad Ostateczny w Kaplicy Sykstyńskiej ukazują postacie o znakomicie widocznej anatomii, ale w nienaturalnych pozach. Czy bohater plakatu przyjmuje niena- 
turalne pozy? Analiza wykazuje, że tak. Wzniesione ręce demonstrujące broń, sztandar, palce wskazujące wymierzone w widza, wzburzone oblicza, operowanie atrybutami - rekwizytami fasady osobistej, wszystko to występowało na wielu plakatach. W plakacie dominuje, jak wspomniałam, realizm rodzajowy, czyli kult przeciętności. Ułatwia to identyfikację masowemu odbiorcy, który jest odbiorcą wirtualnym. Rzadko wykorzystywany jest realizm indywidualny - „portrety” władców, bohaterów, a jeśli, to dla przedstawienia ładu społecznego i lansowania wzoru osobowego. Podsumowując można stwierdzić, że w plakatach występują wszystkie trzy formy realizmu treści, z uprzywilejowaniem realizmu rodzajowego. Realizm formy może polegać na iluzjonizmie, realizmie hierarchizującym według norm obiektywnych, realizmie subiektywnym, realizmie psychologicznym, realizmie socjalistycznym, realizmie genetycznym. Które rozwiązanie zastosowano na analizowanych plakatach? Z pewnością realizm socjalistyczny na plakatach radzieckich (Możdżejko 2001). Warto przypomnieć, że zgodnie z rozumieniem realizmu genetycznego jako odzwierciedlania rzeczywistości przez dzieło sztuki, sztuka dla mas, będąca narzędziem polityki społecznej, w ogóle nie spełnia kryteriów realizmu. Występuje tu iluzjonizm, starający się do złudzenia naśladować rzeczywistość. Iluzja dotyczy raczej przesłania, a nie formy. Czy śliczne pielęgniarki $\mathrm{z}$ amerykańskich plakatów to iluzjonizm czy „realizm amerykański" realizujący ideologiczne założenia? Pojawia się realizm hierarchizujący według norm obiektywnych, gdy kolory są stałe, zgodne z naturą (jest czerwony mundur "krasnoarmiejca”, czerwony ogien, niebieskie niebo, woda, szaroniebieskie samoloty i statki, naturalne kolory kobiecych twarzy, zwłaszcza włosów - brunetki, blondynki). Czy widzimy realizm subiektywny, który w malarstwie był stosowany $\mathrm{w}$ impresjonizmie, ekspresjonizmie, kubizmie? Raczej nie, najwyżej chyba ekspresjonizm, łączący cechy realizmu subiektywnego, psychologicznego i groteski. Ossowski podaje karykaturę jako przykład realizmu psychologicznego. Proponujemy tu wyodrębnić ją jako typową dla groteski.

\section{Groteska}

W literaturze przedmiotu istnieje kilka sposobów definiowania groteski, przede wszystkim za pomocą definicji opisowych, ostensywno-egzemplifikacyjnych, strukturalnych, psychologicznych oraz relacjonal- 
nych (Matuchniak-Krasuska 1999). Pierwsze definicje groteski miały charakter opisowy, ograniczający się do wymienienia elementów roślinnych, zwierzęcych, ludzkich i przedmiotowych tworzących groteskę. Wenecki malarz dworski Arcimboldo stworzył układy roślinnych figur sugerujące ludzkie twarze (seria Pory roku). Polski surrealista Kazimierz Mikulski malował kobiety-drzewa, kobiety-koty (Widok $z$ mojego okna). Podstawową jednostką ikoniczną groteski jest postać groteskowa, ukształtowana na dwóch zasadach. Zasada hybrydacji, polegająca na łączeniu części ludzi, zwierząt, roślin i martwych przedmiotów, prowadzi do powstania typu monstrualnego. Natomiast zasada groteskowej deformacji umożliwia tworzenie typu karykaturalnego (Gryglewicz 1984). Groteskowa deformacja $\mathrm{i}$ hybrydacja polegają na przekształcaniu istniejącego $\mathrm{w}$ naturze wzoru, poprzez procedury animacji, mortyfikacji, reifikacji, heterosyntezy, deproporcjonalizacji.

Postać groteskowa może występować także w dziełach, które jako całość nie mają groteskowego charakteru, np. w rzeźbach i obrazach religijnych z aniołami czy groteskowymi diabłami. Klasyczne motywy groteskowe to chimery i gargulce architektury gotyckiej, postacie demonów i diabłów w sztuce XV i XVI w., renesansowy ornament, postacie z commedia dell'arte, szkielety, monstra, dziwaczne zwierzęta: centaur, meduza, bazyliszek, pegaz, gryf, harpie. Fakt, że groteskowość uwidacznia się w dziele przez postać lub scenę, determinuje wniosek, że groteska należy wyłącznie do świata figuratywnego i nie może występować w sztuce nieprzedstawiającej.

Gilbert Lascault w swoim obszernym dziele znakomicie charakteryzuje monstrualny typ groteskowych postaci, przytaczając ich staranną klasyfikację (Lascault 1973). Praca ta stanowi interesujące studium groteski w plastyce, dostarczające materiału ilustracyjnego do każdego typu definicji analizowanego pojęcia (definicje ostensywno-egzemplifika-cyjne). Klasyfikacja formalna monstrów, zwana niekiedy kartezjańską odnosi się wyłącznie do ich konstrukcji, abstrahuje od znaczenia i symboliki. Monstrualne stwory powstają przez: pomieszanie rodzajów (uczłowieczone zwierzęta, ożywione rośliny czy przedmioty, zezwierzęceni ludzie, ożywieni zmarli), zmianę wielkości (karły, giganci z baśni, mitologii), kompozycję (szokująca ilość, wielkość, układ organów u monstrów hybrydalnych i w karykaturach) oraz niedostateczną determinację cech (brak precyzji detalu, tłum).

Wielu autorów podkreśla, że groteska jest najbardziej niejasną kategorią estetyczną. Nie można jej zdefiniować tylko i wyłącznie poprzez stosowanie wyżej wymienionych form, ale raczej poprzez jej specyficzną struk- 
turę. P. Thomson proponuje cząstkową definicję groteski, wymieniając jej cztery podstawowe cechy: dysharmonię, kombinację komicznego i strasznego, ekstrawagancję, nienormalność (Thomson 1972: 77). G. Harpham opisuje groteskę jako połączenie zadziwiającego i odpychającego (Harpham 1976: 4).

Groteskowe monstrum zawsze pełniło też funkcje dekoracyjne, zwłaszcza w groteskowym ornamencie. Forma groteskowa miała immanentne zalety estetyczne, tak że pomimo swojego peryferyjnego usytuowania na obramowaniu dzieła przyciągała uwagę widza, przyczyniając się do decentralizacji obrazu, a zatem modyfikacji kompozycji.

Relacjonalna definicja groteski polega na ustaleniu jej relacji z innymi kategoriami estetycznymi, takimi jak absurd, fantastyka, horror, karykatura, komizm. Są to pojęcia o krzyżujących się zakresach. Okazjonalnie wspomagają groteskę parodia, trawestacja, burleska, ironia, satyra. Forma estetyczna groteski wymaga użycia wielu kategorii: dekoracyjności, uroku, lęku, piękna, brzydoty, komizmu. Mnożenie tych kategorii ma tę zaletę, że umożliwia zaklasyfikowanie przypadków trudnych do określenia.

\section{Analiza wybranych plakatów}

\section{Plakaty amerykańskie ${ }^{1}$}

Jedenaście amerykańskich plakatów wojennych z lat 1941-1943 ukazuje wyłącznie bohaterów pozytywnych, to jest „swoich”, nie wrogów. Wszystkie są realistyczne, choć uosabiają różne typy realizmu. Atrakcyjna forma służy jako „przynęta”, zachęcająca do zrozumienia treści i do zastosowania się do wskazań przekazu. Funkcje przynęty pełnią uśmiechnięte, ładne dziewczyny w mundurach, ukazane na tle samolotów, statków lub jasnego nieba; zachęty - duże napisy (,zostań pielęgniarką", "wstąp do armii", „służ w marynarce”); informacji - drobne napisy (np. gdzie się zgłosić do wojska). Te trzy plakaty „kobiece” uosabiają „wartości łagodne" w terminologii M. Wallisa, choć są to plakaty wojenne (Wallis 1968). Można je uznać za doskonałe przykłady realizmu rodzajowego,

${ }^{1}$ Omawiane plakaty pojawiają się w tekście K. Biskupskiej, Analiza dyskursywna amerykańskich plakatów rekrutacyjnych okresu II wojny światowej. 
gdyż przedstawione szatynki i blondynki nie są znane z imienia, nazwiska, twarzy. Ułatwia to odwołanie się do masowego odbiorcy i jego ewentualną identyfikację z bohaterka, co sprzyja zastosowaniu się do wezwania. Nie mamy też wątpliwości co do realizmu formy, ale analizy wymaga ocena występujących tu możliwości. Jest to iluzjonizm, a zarazem realizm hierarchizujący według norm obiektywnych i realizm genetyczny, gdyż bohaterki są jak z natury, ze zdjęcia, prawdziwe. Podobną konstrukcję plastyczną mają plakaty „męskie”: z dzielnym marynarzem przy sterze, $\mathrm{z}$ uśmiechniętym piechurem oraz $\mathrm{z}$ maszerującym doboszem. Ważną rolę odgrywają rekwizyty - statki, broń, mundury aktualne lub historyczne (np. z okresu walki o niepodległość Stanów Zjednoczonych). Błękitne niebo $\mathrm{w}$ tle kreuje pogodną atmosferę. Przeważają plakaty plastyczne, o perspektywie hierarchicznej, z ważną postacią usytuowaną centralnie. Nieliczne plakaty mają kompozycję komiksowa z kilkoma informacjami wizualnymi (statki, sylwetki ludzkie) ułożonymi w sekwencję narracyjną i opatrzonymi dłuższym, czasem trudno czytelnym komentarzem. O słuszności sloganu „mężczyźni tworzą marynarkę, a marynarka tworzy mężczyzn" przekonujemy się, porównując rachityczną figurę rekruta $\mathrm{z}$ wyprostowaną sylwetką żołnierza. Postacie przedstawione na małych zdjęciach są niewyraźne, odczytywane jako schematyczne, a zatem karykaturalne. Wykorzystany tu został realizm rodzajowy oraz groteska, z uwagi na niedostateczną determinację cech. We wszystkich plakatach przeważa kompozycja diagonalna, z układem od lewej do prawej, konotującym ruch naprzód, działanie, aktywność. Wszystkie plakaty amerykańskie można określić jako "socrealistyczne" nie z uwagi na okoliczności powstania, ale kompozycję plastyczną i przesłanie - sztuka jest tu narzędziem polityki społecznej.

\section{Amerykańskie plakaty wojenne ${ }^{2}$}

Zestaw trzydziestu plakatów amerykańskich omawiany przez Tomasza Ferenca zawiera przede wszystkim dzieła realistyczne (26), kilkanaście groteskowych i jeden semi-abstrakcyjny. Określenia semiabstrakcyjny używa Roman Ingarden, omawiając warstwową budowę obrazów, dla wskazania takich, w których formy plastyczne sugerują

${ }^{2}$ Omawiane plakaty znajdują się w tekście Tomasza Ferenca, Bohater, wróg, zdrajcaamerykańskie i niemieckie plakaty z okresu II wojny światowej. 
wygląd przedmiotów przedstawianych (Ingarden 1966; 1970). W przypadku plakatu, kolorowe zgeometryzowane formy sugerują godła Japonii, Niemiec, USA.

Plakaty realistyczne, operujące realizmem rodzajowym $\mathrm{w}$ warstwie treściowej, a realizmem obiektywnym i genetycznym $\mathrm{w}$ warstwie formalnej, ukazują z reguły zwykłych ludzi - kobiety, dzieci, osoby starsze, całe rodziny $\mathrm{w}$ sytuacjach codziennych. To nasz świat społeczny do obrony. Iluzyjność formy pojawia się raczej przy wątku pracy dla ojczyzny, gdy nasi bohaterowie, kobiety i mężczyźni mają produkować bomby, kupować bony, oszczędzać. Pracują kobiety, wszystkie śliczne i zadowolone, pracują mężczyźni, wszyscy muskularni i dzielni. Są czarni i biali, razem i oddzielnie. Nawiązując do koncepcji podmiotu lirycznego w poezji, można powiedzieć, że podmiot plastyczny tych plakatów da się wpisać pod dużym kwantyfikatorem - to MY, wszyscy Amerykanie. Obrazy pięknych kobiet odpowiadają "portretom uślicznionym” przewidywanym w firmie portretowej Witkacego.

Groteskowe rozwiązania rzadko dotyczą „swoich”, gdyż deformacja i brzydota, mające negatywną konotację, lepiej „pasują" do wrogów. Kilka plakatów ilustruje cierpienie i poświęcenie dla ojczyzny poprzez ukazanie zmęczonego żołnierza, spadochroniarza, piechura, skazanego na śmierć przykutego jeńca z zasłoniętą głowa; formalnie jest to groteskowe monstrum o niedostatecznej determinacji cech. Jedynym optymistycznym, a jednocześnie groteskowym dziełem jest plakat pokazujący amerykańskie samoloty i orły $\mathrm{w}$ locie. Wykorzystane są tu groteskowe hybrydy złożone $\mathrm{z}$ elementów ptasich i przedmiotowych - orzeł ma na skrzydłach oznaczenia sił powietrznych USA.

Plakaty groteskowe z reguły ukazują wroga. Zastosowano groteskę fantastyczną ukazującą potwory, gady (plakat ukazujący wojskowy but rozgniatający kłębowisko węży) oraz groteskę satyryczna, operującą karykaturą (wykrzywione twarze wojskowych japońskich i niemieckich). Warto zauważyć, że ten sam motyw plastyczny, żołnierski but, raz bywa butem naszego żołnierza niszczącym wroga - gadzinę, a raz butem wroga (oznaczonym swastyką) - miażdżącym dach naszego kościoła. Są to buty - olbrzymy czy raczej buty olbrzyma, co jest groteskowym zachwianiem proporcji. Typowe groteskowe monstra widnieją na plakacie ukazującym wroga w hełmie - monstrum o niedostatecznej determinacji cech. Na plakacie pokazującym na pierwszym planie osiłka o nagim torsie, zbierającego czaszki w surrealistycznym krajobrazie znanym $\mathrm{z}$ obra- 
Między groteską a realizmem...

zów Savadora Dali, jest monstrum o szokującej wielkości i muskulaturze. Jest to też realizm poszczególnych składników treści. Za pierwszym gigantem podążają kolejni, mniej widoczni na drugim i trzecim planie, a zatem również monstra o niedostatecznej determinacji cech. Jest to typowe rozwiązanie dla ukazania tłumu.

\section{Plakaty niemieckie ${ }^{3}$}

Trzydzieści plakatów niemieckich zrealizowanych jest niemal wyłącznie w konwencji realistycznej i groteskowej. Jedyny plakat plastyczny semi-abstrakcyjny ostrzega matki przed pożogą wojenna, a napis jest umieszczony na czerwono-czarnym tle. Nieliczne plakaty groteskowe, operujące deformacją i karykatura, ukazują Żydów i bolszewików, czyli wrogów. Są to monstra o zaburzonych proporcjach, jak baśniowe karły czy giganci (olbrzymie nosy i uszy, złe spojrzenia). Groteskowym monstrum - robotem złożonym z elementów przedmiotowych imitujących ludzkie członki - jest „amerykański potwór” zagrażający europejskiej (czytaj: niemieckiej) kulturze. Gigant depcze miasto. Bomby tworzą nogi, bęben brzuch, flaga żydowska przysłania krocze, klatka na niewolników to klatka piersiowa. Głowa okryta jest charakterystycznym kapturem Ku Klux Klanu. Para czarnych rąk spętanych wisielczym sznurem dzierży czarną płytę winylową i sakiewkę z dolarami, a para białych dłoni - pistolet i granat. Na ramionach potwora siedzą dwie miniaturowe Miss America, jedna prezentuje indiański pióropusz, a druga amerykański sztandar. Z jego ramion wyrastają skrzydła samolotowe. Jest to hybryda przedmiotowo-ludzka o nadmiarze organów i zaburzonych proporcjach. Wykorzystane są tu cechy groteski fantastycznej i satyrycznej.

Groteskowy charakter mają dwa proniemieckie plakaty, o podniosłym nastroju. Jeden ukazuje czarnego wspaniałego orła i niemieckie flagi powiewające na wietrze, wspólnie konotując przestrzeń, powietrze, ruch, dumę. To prawdziwy orzeł, a jednocześnie orzeł - godło, co sprawia, że realizm łączy się z groteską. Na drugim niemiecki czarny orzeł dzierży w szponach glob ziemski. Jest tu zaburzenie realiów i proporcji, typowe dla groteski, zwłaszcza surrealistycznej.

${ }^{3}$ Omawiane plakaty znajdujemy w tekście Tomasza Ferenca, Bohater, wróg, zdrajcaamerykańskie i niemieckie plakaty z okresu II wojny światowej. 
W całej serii przeważają plakaty realistyczne, operujące realizmem rodzajowym (żołnierze, kobiety, członkowie Hitlerjugend). Znajdujemy bezdyskusyjną egzemplifikację „wierności indywidualnej” na plakatach - portretach przedstawiających Hitlera, w dostojnej pozie, ubranego w galowy mundur. Stylistyka odpowiada klasycznym portretom koronacyjnym. Ilustruje ideę: ,jeden wódz, jeden naród", widniejącą zresztą na jednym z plakatowych portretów. Na kolejnym, ukazującym uśmiechniętego Führera z dziećmi, realizm jednostkowy (Hitler) łączy się z realizmem gatunkowym (dzieci, jakieś dzieci, nasze dzieci, wszystkie dzieci). $\mathrm{Na}$ innym wielki Hitler - zajmujący całą płaszczyznę obrazu - stanowi tło, na którym widnieje dzielny młodzieniec z Hitlerjugend. Taki układ graficzny, pomijając sugestywny komentarz, konotuje ideę wzorowania się na „wodzu”. Na innych zamiast wodza widnieją flaga i inne atrybuty hitlerowskie, a na ich tle bohater czy bohaterka obrazu: urodziwi, pogodni, wcielający w życie wskazania wodza i partii. Warto zauważyć, że bohaterami obrazu, z którymi Niemcy mieli się identyfikować, są małe dzieci, dziesięciolatki, młodzi ludzie obu płci, gdyż przekaz miał docierać do wszystkich, poprzez odwołanie do każdego. Odbiorca wirtualny jest zatem odnoszony do określonej kategorii społeczno-demograficznej. Jest tu zastosowana zasada kultury masowej łącząca „wspólny mianownik” (,jeden wódz, jeden naród”, „Niemcy ponad wszystko”) z homogenizacją mechaniczną („,dla każdego coś miłego"). Ten chwyt można nazwać „zindywidualizowaną masowością". Wszystkie omówione powyżej plakaty wojenne posługują się realizmem treści i formy, i mają wydźwięk optymistyczny, operują wartościami uznanymi i uroczystymi (co do treści) oraz wartościami wzniosłymi (co do treści i formy). Korzystam tu z koncepcji S. Ossowskiego i M. Wallisa (Ossowski 1966; Wallis 1968).

Kolejna grupa plakatów przedstawia grozę wojny. W tle umieszczono krajobraz bitwy, pożogi wojennej lub akcesoria zbrojne, a na pierwszym planie widnieje walczący bohater: żołnierz piechoty, marynarki, lotnictwa, batalionu narciarskiego, wieśniak, kobieta żegnająca żołnierza idącego na front, kobieta podczas orki pole (mężczyźni przecież walczą).

Podsumowując, można policzyć pewne formalne i tematyczne kategorie plakatów. "Swoich" ukazuje ponad 20 z nich, „obcych" - niespełna 10. Podniosłych jest kilkanaście, radosnych - kilka, straszących - blisko 10. A zatem odwołują się do "swoich", stosując raczej techniki pozytywne. Czy można mówić o optymizmie plakatów wojennych? Czy kolejne tematy i dostosowane do nich formy plastyczne zmieniały się w czasie wojny? To pytania, na które odpowiedzieć może bardziej analiza treści i kontekstu. 


\section{Plakaty radzieckie ${ }^{4}$}

Prawie 50 plakatów radzieckich z lat 1941-1945 operuje zarówno groteska jak i realizmem, można powiedzieć, że $\mathrm{w}$ równych proporcjach. Wszystkie groteskowe plakaty (ponad 20) ukazują wroga, zwłaszcza w ujęciu satyrycznym - karykaturalnym (ponad 10). Są też typy mieszane, satyryczno-fantastyczne, interesujące z plastycznego punktu widzenia. Wszystkie karykaturalne ujęcia z definicji należą do groteski, a także realizmu psychologicznego (realizm formy). Jeśli identyfikujemy konkretną postać, jest to „wierność indywidualna” - realizm treści; dotyczy to kilkunastu przedstawień Hitlera. Na 10 plakatach pojawia się karykatura Hitlera: deformacja sylwetki, wyeksponowanie charakterystycznych cech twarzy - opadająca grzywka, wąsy, wydłużony nos i broda. Ta postać ukazana jest $\mathrm{w}$ rozmaitych, tragikomicznych sytuacjach. Podczas audiencji, wobec stojącego na baczność podkomendnego trzyma głowę na krześle i czapkę wojskową na wypiętym siedzeniu. Bywa też upozowany na Napoleona, na tle cesarza Francuzów i w kapeluszu o stosownym fasonie. Na plakacie 7, Lekcja Niemcom, głowa Hitlera otwiera się niczym pojemnik z pokrywką - to też groteska z elementów ludzkich i przedmiotowych. Na plakacie 6 tytułowa dojna krowa koloru złota okryta księgą Mein Kampf i w związku z tym dająca złoto, ma krowią mordę o charakterystycznych cechach twarzy Hitlera, wspomnianych wyżej. To metafora plastyczna, gdyż jedna forma plastyczna - signifiant oznacza dwa różne signifié - krowią mordę i głowę Hitlera. Na plakacie 1 Hitler ma ręce szpony/cęgi, czyli elementy z innych uniwersów ludzkiego, zwierzęcego i przedmiotowego. Na plakacie 5 pokazana jest "maszyna do łgania”, będąca połączeniem karabinu i ludzkiej głowy wypluwającej ulotki propagandowe. A zatem jedno dzieło wykorzystuje równocześnie groteskę satyryczną i fantastyczną. Arcydziełem gatunku jest "transformacja Fryców" z maszerujących żołnierzy - normalnych ludzi - w swastyki, przedmioty o drewnianych i ludzkich nogach, a następnie - w krzyże nagrobne (plakat 14). Czerwone cęgi z datami 19411944 ściskają głowę Hitlera, który zrozpaczony klęską pod Stalingradem usiłuje się zastrzelić. Na innym plakacie widnieje leżący Niemiec na stosie trupich czaszek (to realizm rodzajowy). Scenę wyjaśnia jeden napis -

\footnotetext{
${ }^{4}$ Omawiane plakaty znajdują się w tekście P. Chomczyńskiego, „Wielka wojna ojczyźniana" na plakatach sowieckich.
} 
Stalingrad. Odwrót Niemców, pobitych i zmarzniętych (biały krajobraz), nad którymi góruje zwycięski radziecki bohater na czerwonym tle, widnieje na kilku plakatach $(16,45,46,47,48)$, odwołujących się też obrazem i słowem do historii, zwłaszcza napoleońskiej. Rosjanie walczyli zwycięsko widłami, mieczami, karabinami, czołgami. Wątek ten występuje na każdym z serii plakatów, konstruując logiczną układankę z podanych przesłanek: „Rosja zawsze zwycięża”. Wróg bywa też olbrzymim człowiekiem niszczącym bezbronną ludność (zwłoki kobiety i dziecka na pierwszym planie) i jej siedziby (płonące domy w tle). To groteskowe monstrum o zachwianych proporcjach. Podstępny wróg jest też wilkiem ze swastyką przebranym w skórę baranka (pomieszanie elementów z różnych uniwersów, metafora wizualna ilustrująca znane porzekadło).

Realistyczne i optymistyczne są plakaty o żołnierzach radzieckich walczących z wrogiem. Są ukazani w konwencji realizmu gatunkowego, $\mathrm{z}$ atrybutami stosownymi do roli (mundur, broń), jasnymi i uśmiechniętymi twarzami, co - zgodnie z Goffmanowską analizą aktora społecznego - ma wskazywać na jego stosunek do roli. Jest piechota, marynarka, lotnictwo, czyli „wszyscy” walczący „za ojczyznę" i „dla sławy”, jak głoszą duże napisy. To sceny z happy endem. Są też sad stories, ukazujące cierpienie i motywujące żołnierzy radzieckich do obrony, zwłaszcza kobiet i dzieci, z napisami „ratuj” (plakaty 23, 24, 25, 26). Często kobiety o surowych obliczach nie proszą o ratunek, ale nakazują walkę za matkę i ojczyznę. Kobiety w czerwonych strojach są personifikacją ojczyzny, to też przykład metafory wizualnej (plakaty 27, 28, 29).

Kolejna seria posterów instruuje ludność cywilna, jak zachowywać się w czasie wojny. Prowadzą walkę partyzancką sabotaż, dzielnie pracują na polach i w fabrykach, nie tracą czasu na próżnowanie i "gadanie". Stylistyka tych plakatów jest stricte socrealistyczna w treści, formie, przesłaniu („,kobiety dla ZSRR, Ural dla frontu”). Socrealistycznej konwencji ideologicznej służy nawet malarski realizm. Gdyby nie napisy, plakaty 25 i 26 przedstawiające młodą dziewczynę oraz żołnierza trzymającego na ramieniu dziecko, byłyby po prostu pięknymi obrazami. Radzieccy bohaterowie pracy i walki zawsze są ukazani realistycznie, a wróg z reguły jest obiektem groteskowej deformacji. Konwencja ta jest wyraźnie widoczna na plakacie 35, gdyż jest użyta w jednym przekazie ikonicznym, który $\mathrm{w}$ związku $\mathrm{z}$ tym uosabia wielość rzeczywistości w sztuce i niespójną formę (zgodnie z koncepcją Leona Chwistka). 
Między groteską a realizmem...

\section{Plakaty radzieckie ${ }^{5}$}

Ponad 30 plakatów z okresu wojny polsko-bolszewickiej 1919-1920 operuje głównie groteską. Forma plastyczna jest zdominowana przez tekst i narrację komiksową (kilka małych obrazków z podpisami). Są zatem trudniejsze w odczytaniu "na pierwszy rzut oka”. Od razu widać charakterystyczną postać Lenina w czapce, widać króla, szlachcica, chłopa, świnię, ale bez odczytania tekstu nie wiadomo o co chodzi. Polski odbiorca ze zdziwieniem dowiaduje się, że świnia tresowana we Francji to Polska lub że ,jaśniepańska" Polska to pies w czapce z pawim piórem. Typowe dla groteski satyrycznej, w bajkach i w obrazach, jest wykorzystywanie zwierząt do ukazania przywar ludzkich. Radziecki wieśniak jest przestrzegany przed polskim panem i polskim kułakiem, a żołnierz zachęcany do ruszenia na polski front. Wykorzystany jest też typowy motyw cierpienia "swoich" (Rosjan, Ukraińców), a znęcania się „wrogów" (tu: Polaków, panów). Polski pan przybija do krzyża Ukrainę, uosabianą przez młodą kobietę; Polacy utożsamiani są z wandalami. Światowy imperializm przedstawiany jest jako smok, typowe groteskowe monstrum, a kapitaliści jako wielka trójka grubasów (monstra przez deformację organów).

Interesujące jest powtarzanie nie tylko motywów, ale całej plastycznej kompozycji, jak w plakatach 28 i 40, a zwłaszcza 13 w późniejszej serii radzieckiej z II wojny światowej „każde uderzenie godzi we wroga”. Podobne powtórzenie motywów występowało też w plakatach amerykańskich „,z olbrzymim butem” (groteska).

$\mathrm{Na}$ kilku plakatach radzieckich, podobnie jak w plakatach niemieckich, wykorzystano motyw kosmiczny. „Nasz” bohater dzierży glob ziemski, niczym w pieśni z tej epoki „ruszymy z posad bryłę świata, dziś niczym jutro wszystkim my". Lenin wymiata z ziemi carów, panów, kapitalistów. Jest tu groteskowe zachwianie proporcji, „wierność indywidualna" (Lenin), realizm rodzajowy (pozostałe postaci). Na plakacie 32 czerwonogwardzista rozpoznawalny przez mundur i kolor (odpowiada ideologii, a nie rzeczywistej barwie uniformu) depcze po mapie Europy, od Morza Czarnego po Bałtyk. Na plakacie 25 schematycznie nakreślona

\footnotetext{
${ }^{5}$ Omawiane plakaty wykorzystane zostały w tekście W. Dymarczyka, „Hej! Kto Polak na bagnety" kontra "Obronimy zdobycze Października". Polskie i radzieckie plakaty wojenne próba zrozumienia.
} 
sylwetka czerwonego człowieka uwięziona jest w klatce globu ziemskiego, nakreślonej niczym siatka kartograficzna. W kolejnej sekwencji komiksu bohater uwalnia się z zamknięcia, rozpościera czerwony sztandar i depcze czarnego ludzika, uosabiającego pana. To groteskowe postaci przez zaburzenie proporcji oraz niedostateczną determinację cech.

Arcydziełem plastycznym jest abstrakcyjny plakat Lisieckiego Czerwonym klinem bij białych. Interesujące są też plakaty w konwencji awangardy początku wieku XX, o zgeometryzowanej formie. Nowatorscy artyści realizowali sztukę socrealistyczną $\mathrm{w}$ ideologii, ale nie $\mathrm{w}$ wyrazie plastycznym, co jak wiemy z historii nie spotkało się z przychylnością władz radzieckich ani wobec dzieł, ani autorów (plakat 5 Trzeba pracować).

Wszystkie plakaty są ilustracją tekstu Międzynarodówki, ukazują dychotomiczną strukturę świata i dziejów. Kształtują słuszne postawy poświęcenia i pracy $\mathrm{u}$ "człowieka radzieckiego". Tylko nieliczne można uznać za realistyczne: polski z polskim tekstem "niech żyje rewolucja” i czerwonymi postaciami (14) oraz z postaciami polskiego szlachcica i jego „pomocnika” (31).

\section{Plakaty polskie $^{6}$}

Seria ponad 20 plakatów zawiera 17 plakatów realistycznych i 6 groteskowych. Bywają plakaty "mieszane” z elementami realizmu i elementami groteski. Groteskowy jest potwór bolszewicki, naprawdę straszny i w ogóle nie śmieszny według kryteriów psychologicznej definicji groteski. Jest natomiast groteskowy z uwagi na konstrukcję formalną - poprzez zachwianie proporcji (jest olbrzymi, rękami rozwala domy). Jest tworem hybrydalnym - składa się elementów pochodzących $\mathrm{z}$ różnych uniwersów: człowiek i przedmiot (jak potwór z nożem $\mathrm{w}$ zębach), śmierć, człowiek i koń (konwencja la danse macabre), człowiek i śmierć na stosie czaszek, człowiek-pojazd, a malutkie ludziki ciągną „czerezwyczajkę". W tej grotesce jest też realistyczna "wierność indywidualna” ludzie potwory to Lenin i Dzierżyński. Na tle czarnej sylwetki „krasnoarmiejca" widnieje mężczyzna z wyciągniętymi rękami, kroczący niczym King Kong, a oznaczony pięcioramienną gwiazdą. Napis „znowu

${ }^{6}$ Omawiane plakaty znajdują się w tekście W. Dymarczyka, „Hej! Kto Polak na bagnety" kontra "Obronimy zdobycze Października". Polskie i radzieckie plakaty wojenne - próba zrozumienia. 
żydowskie łapy, przenigdy" pasuje do kompozycji plastycznej. Pod hasłem „do broni” polski żołnierz, ukazany zgodnie z regułami realizmu rodzajowego, walczy z bolszewickim czerwonym potworem - wielogłowym smokiem (typowe groteskowe monstrum). Kompozycja - żołnierz ustawiony tyłem do widza dźga atakującego potwora - ułatwia identyfikację z obrońcą ojczyzny i budzi poczucie zagrożenia (gdyby nie żołnierz, potwór zaatakowałby mnie).

Realistyczne plakaty są malarskie (10), obrazowe w formie i treści. Odpowiadają polskiemu malarstwu historycznemu z wieku XIX, ulubionemu przez polskich odbiorców do tej pory. Żołnierze i ułani jak z obrazów Kossaka, chłopi jak z Chełmońskiego i Michałowskiego, kobiety jak z Grottgera. To swojska stylistyka, wartość znana, uznawana i odczuwana. W tej konwencji są ukazani "swoi”. Niepodległa Polska to dziewczyna lub kobieta $w$ białej szacie ze sztandarem $z$ białym orłem albo w czerwonej szacie z białym orłem. Warto zauważyć, że na plakatach te same kolory konotują różne treści. Kobieta w czerwonej szacie z białym orłem kojarzy się z Polska, a nie Rosją radziecką (na plakatach niemieckich zawsze był czarny orzeł). Symptomatyczny jest też wątek religijno-patriotyczny na plakacie ukazującym kilka symboli Polski: obraz Matki Boskiej Częstochowskiej, białego orła, husarzy stojących na straży i napis "pod Twoją obronę". Na innym plakacie, wzywającym do zaciągnięcia się pod sztandary orła i Pogoni, widnieje obraz Matki Boskiej Ostrobramskiej, patrzącej z nieba jak polski żołnierz, broniąc matki z dzieckiem, kłuje bagnetem Kozaka w czerwonej rubaszce i czapce. Na kilku plakatach widnieją sceny walki polskiego żołnierza czy polskiego społeczeństwa $\mathrm{z}$ bolszewickim najeźdźca, uwzględnionym na obrazie (jak plakaty 22 i 49) lub sugerowanym, nie ujętym w kadrze $(19,20,48)$. Cytowane słowa pieśni religijnych i patriotycznych dobitnie tłumaczą sens kompozycji pikturalnej, sugerują interpretacje („twierdzą nam będzie każdy próg”, ",hej! Kto Polak na bagnety").

„Wierność indywidualna" dotyczy realistycznie ukazanego Naczelnika Państwa Marszałka Józefa Piłsudskiego, jadącego na białym koniu (a nie na kasztance) na tle polskiego sztandaru, w otoczeniu "szarej piechoty" i witanego przez ludność. Wierność indywidualna łączy się z realizmem rodzajowym.

Jest też jeden plakat komiksowy $\mathrm{z}$ dwiema scenkami ukazującymi żołnierza i chłopa zachęcanego do zaciągnięcia się do wojska oraz chłopa bitego przez bolszewików, ze stosownym napisem. Inny pokazuje górala atakującego niewidocznego wroga - bolszewika; opatrzony jest napisem 
po rosyjsku. To Rzeczypospolita obojga narodów walczy przeciw Rosji sowieckiej. Podobnie jeden plakat z komentarzem po polsku pojawił się w serii posterów radzieckich. Walka o pogranicze jest wyraźna.

\section{Plakaty hiszpańskie ${ }^{7}$}

Seria 21 plakatów hiszpańskich z okresu 1936-1939 wykorzystuje zarówno rozwiązania realistyczne, jak i groteskowe. Uderzająca jest natomiast kolorystyka tych plakatów, są bardziej kolorowe niż wszystkie pozostałe serie "narodowe". Wszystkie odwołują się do "swoich" i do ojczyzny, przywoływanej werbalnie (duże napisy Espana) lub ukazywanej graficznie poprzez personifikację (dostojna niewiasta). Środkami plastycznymi nie są ukazywani wrogowie, najwyżej rezultaty ich zbrodniczej działalności - np. seria zdjęć pomordowanych dzieci. Realizm treści typu „wierność indywidualna” zastosowany jest w plakatach „portretowych" (plakat 21 - postać generała Franco), w pozostałych przypadkach (np. plakaty 9, 14, 16) przeważa realizm rodzajowy - widzimy mężczyzn, kobiety, kobiety z dziećmi, walkę czy akcesoria bojowe (jak mundur na plakacie 13, broń na 9,16, 17,). Wykorzystany jest też kilkakrotnie realizm gestu - bohaterowie wyciągają ręce dzierżące karabiny, eksponują muskuły, z okrzykiem biegną naprzód, „,ku lepszej przyszłości” (plakaty $1,2,9,16,17)$.

Niektóre plakaty stosują realizm formy w kilku odmianach: iluzjonizm (ujęcia "portretowe" i zdjęcia, jak na plakatach 21 i 6, 10), realizm obiektywny (plakaty 9, 13, 14, 15, 17), realizm subiektywny (,te kolorowe" $2,3,12$ ) i socrealizm (wszystkie, z uwagi na funkcje ideologiczne).

Groteskowe plakaty istnieją w wersji negatywnej i pozytywnej. Te pierwsze służą ukazaniu wrogiego "generalissimusa". Interesujące jest, że są to dwa zupełnie różne satyryczne "portrety" konkretnej postaci historycznej. Obydwa realizują istotę groteski „straszne i śmieszne zarazem", ale jeden jest zdecydowanie śmieszny (plakat 7), gdy drugi raczej straszny (plakat 8). Pierwszy przypomina ilustrację z książeczek dla dzieci; ukazuje wesołego jeźdźca w kolorowym mundurze na zabawnym koniku. Groźne atrybuty są ukryte w detalach: konik ma na zadzie wytatuowaną swastykę, z chmurki na niebie lecą bomby, a kaktusy deptane

${ }^{7}$ Omawiane plakaty wykorzystano w tekście M. Melnyk, Obraz hiszpańskiej wojny domowej na plakatach. 
końskimi kopytami mają ludzkie twarze. Warto przypomnieć tu kompozycje Arcimbolda ukazujące ludzkie oblicza złożone z elementów roślinnych. Na drugim widnieje gigantyczny potwór mający cechy człowieka, kościotrupa i robota (monstrum przez pomieszanie cech i zmianę wielkości), kroczący $\mathrm{w}$ mundurze oznaczonym swastyką, za nim podążają wspierający go trzej malutcy notable w stroju świeckim, w mundurze wojskowym i w szatach duchownych. Ponura scena przedstawiona jest $\mathrm{w}$ ciemnych barwach. Warto ją zestawić ze wspomnianym wyżej realistycznym portretem generała, pogodnym, pochlebnym, optymistycznym. Przekaz plastyczny ukazuje wprawdzie konkretną postać, ale sposób prezentacji ujawnia postawy autora i odbiorcy wirtualnego.

Pozytywnym monstrum jest gigantyczny czerwony żołnierz kroczący z karabinem przez krajobraz sielskiej wsi i chroniący pracujących w polu chłopów. To stróż normalności i ładu.

Jedyny plakat semi-abstrakcyjny (plakat 3), o zgeometryzowanej kompozycji i mocnych barwach, ukazuje promienne słońce i lufę armaty, a napisem obwieszcza zwycięstwo komunistów. Zgeometryzowaną kompozycję ma plakat 12, ukazujący szlachetny profil żołnierza w hełmie. Zarówno twarz, jak i hełm namalowane są nierealistycznymi dla tych obiektów kolorami układającymi się we flagi narodowe (tu kolory są realistyczne). To groteska przez pomieszanie rodzajów (człowiek przedmiot). Podobne rozwiązanie konstrukcyjne zastosowane jest na plakacie 20, ukazującym zmartwychwstałą Hiszpanię - wyniosłą postać ludzką, w szatach raczej niewieścich, a o obliczu raczej męskim, opatrzoną skrzydłami. Warto zauważyć, że są to identyczne chwyty groteskowe, choć graficznie zupełnie różne (geometryzacja - malarskość, uschematyzowany portret - scena rodzajowa). Równocześnie bardzo podobne graficznie plakaty 19 i 20 trzeba odmiennie ocenić wedle głównego kryterium analizy: 19 jest realistyczny, a 20 groteskowy. Także w tej serii obecny jest plakat "kosmiczny" (18) - na globie ziemskim widnieje zarys Hiszpanii i krzyż krucjaty. Interesujące jest też zestawienie plakatów 17 i 18 pod kątem "planów filmowych": na pierwszym widzimy zbliżenie i ujęcie detalu (dłoń wznosząca karabin), na drugim - daleki plan „kosmiczny".

Charakterystyczne jest również połączenie konwencji realistycznej i groteskowej, występujące na plakacie 14. Główni bohaterowie - mężczyzna, kobieta i dziecko - są ukazani w konwencji realistycznej. Jest to $\mathrm{w}$ dodatku scena sielska, spaceru $\mathrm{z}$ pieskiem $\mathrm{w}$ zielonym krajobrazie. $\mathrm{Z}$ postawy wszystkich, $\mathrm{z}$ pieskiem włącznie, promieniuje radość. Posta- 
cie ustawione są na linii diagonalnej od lewego dolnego rogu do prawego górnego, co sugeruje drogę naprzód, w świetlaną przyszłość. Groteskowe elementy są peryferyjne, z uwagi na wielkość i usytuowanie. Na symbolicznej biało-czerwonej planszy silne ramię dźga nożem paszczę smoka. Takie zestawienie jest typowe dla klasycznej groteski fantastycznej, baśniowej, gdy groźne elementy są częściowo ukryte (paszcze smoka za góra, rogi diabła pod kapeluszem, kopyta w butach, a ogon tylko trochę wystaje spod płaszcza). W arrasach monstra umieszczane były na bordiurze, jako elementy dekoracyjne, co łagodziło ich oddziaływanie budzące strach, wstręt, niechęć. Rewolucyjny plakat stosuje więc tradycyjne rozwiązania plastyczne, i to raczej królewskie niż plebejskie.

\section{Polskie plakaty powojenne z lat $1945-1956^{8}$}

W serii prawie 20 plakatów polskich z lat powojennych występują plakaty groteskowe (6), realistyczne (7) oraz "mieszane”, to jest zawierające elementy realizmu i groteski $\mathrm{w}$ jednym przekazie plastycznym (5). Nie ma żadnego plakatu abstrakcyjnego, co może wiązać się z ideologicznym potępieniem takiej konwencji plastycznej zarówno ze względów formalnych (,,sztuka zdehumanizowana” według J. Ortegi y Gasseta), jak i ideologicznych (sztuka niepodporządkowana socrealizmowi).

Groteska w wersji karykaturalnej służy napiętnowaniu i wyśmianiu przeciwnika politycznego - wroga wewnętrznego. W analizowanej serii plakatów nie pojawia się groteska fantastyczna; hybrydalne monstra nie pasują do realizmu socjalistycznego. Niemniej jednak można zauważyć heteronomiczne konstrukcje łączące elementy z różnych uniwersów, np. "uczłowieczone litery” na plakacie $3 x$ TAK. „K" wyposażone w ludzką obutą nogę kopie, jak wyjaśniają podpisy, senatorów, obszarników i fabrykantów oraz Niemców. Są to śmieszne, schematycznie nakreślone ludziki, a zatem monstra o niedostatecznej determinacji cech, ale $z$ charakterystycznymi dla roli społecznej atrybutami, jak okulary, kapelusz, mundur ze swastyką. Bez podpisów nie byłoby wiadomo, kim są. Taka

${ }^{8}$ Omawiane plakaty znajdują się w tekście M. Forc, Motywy militarne w polskiej propagandzie komunistycznej w latach 1944-1956. 
informacja werbalna tworzy tzw. fałszywą koniunkcję, sugeruje, że wymienione podmioty należą do jednego zbioru. Wróg klasowy utożsamiany jest też z wrogiem narodowym, co wzmacnia siłę propagandową plakatu. Ten sam mechanizm jest zastosowany na plakacie opatrzonym hasłem „Z faszyzmu Polskę oczyścimy”, gdzie olbrzymia miotła - główny element kompozycyjny obrazu - wymiata małe ludziki i ich atrybuty: swastyki, odznaki SS, napisy z nazwami hitlerowskich instytucji (Arbeitsamt) oraz polskich konspiracyjnych ugrupowań patriotycznych, jak NSZ. Na plakacie wyborczym, głoszącym "Nie chcesz kapitalistów głosuj 3 razy TAK", na pierwszym planie widnieje opasły burżuj siedzący na robotniku, który porusza się na czworakach. Zastosowano tu groteskową procedurę reifikacji, człowiek jest traktowany jak przedmiot. Równocześnie jest to dobry przykład metafory plastycznej, gdzie jedno signifiant odsyła do dwóch signifié: człowieka - upodlonego robotnika oraz przedmiotu - siedziska pojazdu. Rozwiązanie takie zastosowane jest na znanych obrazach Andrzeja Wróblewskiego Ukrzesłowiona (kobieta wręcz zrośnięta z krzesłem) czy Jerzego Dudy-Gracza Fucha czyli Jeźdźcy Apokalipsy (trzej robotnicy ciągną betoniarkę niczym konie sanie na obrazie Józefa Chełmońskiego). Wykorzystane są też elementy dekoracji scenicznej - w oddali widnieją fabryki z dymiącymi kominami, oraz fasady osobistej - obok robotnika leży młotek, a ubrany w garnitur i melonik kapitalista trzyma teczkę i pali fajkę.

Tytułowy bruderszaft piją dwa człeko-szkielety (przykład groteskowej mortyfikacji) z pucharów nie będących zwykłymi naczyniami, a nakryciami głowy, określającymi aktora społecznego (cylindrem z amerykańską flagą i hełmem ze swastyką). I w tej serii pojawia się plakat "kosmiczny", stosujący groteskowe rozwiązania polegające na zachwianiu proporcji. Wesoły wędrowiec z tobołkiem na plecach kroczy przez mapę Polski ku Wrocławiowi „Nad Odrę, po ziemię ojców i dobrobyt”. Warto podkreślić, że ruch z prawej strony obrazu ku lewej konotuje przyjazd, powrót, i to w sposób niedostrzegalny dla potocznego odbiorcy. Kompozycja obrazu wzmacnia wyraźnie jego przesłanie werbalne. Odbiorca z lat powojennych, podobnie jak odbiorca współczesny, w podobny sposób postrzega mapę Polski i Europy. Po prawej stronie jest wschód, a po lewej zachód. Bohater obrazu uosabia zatem tzw. repatriacje z polskich Kresów na Ziemie Odzyskane Zachodnie i Północne. Tysiące polskich wysiedleńców, dobrowolnych i przymusowych, opuszczało wówczas ojczyznę prywatna, ziemię ojców, wybierając ojczyznę ideologiczną - ziemię swojego narodu, ale nie ojcowiznę. Zmieniły się 
przecież granice państwowe. Manipulacja ideologiczna plakatu polega na zmianie informacji i sugerowanych emocji bohaterów obrazu oraz rzeczywistości historycznej, a tym samym stymulowaniu określonej percepcji tej sytuacji przez odbiorcę. Dzieje były tragiczne, także niesprawiedliwe, a obraz jest wesoły, w treści i formie, w przekazie werbalnym i wizualnym.

Na kolejnym obrazie robotnicza dłoń wpycha czarny walec w "paszczę" łysego okularnika. Gdyby nie napis "bomba atomowa” na tym przedmiocie i podpis „Truman” pod karykaturalnym portretem, widz nie zrozumiałby, o co tu chodzi. Komentarz werbalny czyni kompozycję plastyczną zrozumiała. Jest to dobra ilustracja specyfiki plakatu - przekazu mieszanego werbalno-ikonicznego. Klasyczne eksperymenty z psychologii percepcji wskazywały, jak informacja słowna (np. tytuł) steruje odbiorem formy plastycznej.

Plakaty "mieszane”, wykorzystujące równocześnie postacie groteskowe i postacie realistyczne, dobitnie wykazuja, że realizm jest stosowany do pokazania dobrych „swoich”, groteska zaś służy nakreśleniu złego wroga. Na monochromatycznym, znakomitym plastycznie plakacie „Strzeż tajemnicy służbowej, może właśnie tobie wróg chce ją wyrwać", nasz bohater, robotnik $\mathrm{w}$ roboczym stroju, czapce na głowie, $\mathrm{z}$ narzędziami $\mathrm{w}$ ręku, jest ukazany realistycznie. Ocena taka dotyczy treści - jest to realizm rodzajowy, gdyż widzimy jakiegoś typowego robotnika. Równocześnie jest to realizm formy według norm obiektywnych (czytelna postać), choć z uwagi na kolor - jednolitą jasnoszarą barwę całej postaci - jest to realizm subiektywny. Jasne kolory, zwłaszcza przy kontrastowym zestawieniu barw, mają pozytywną konotację. Nasz robotnik jest zatem bohaterem pozytywnym. Za nim w tle czai się ciemna sylwetka mężczyzny w płaszczu i kapeluszu - to tajniak, tajemniczy wróg. Niebieska poświata - jedyny kolor obok dominujących czerni i szarości - jest także wariantem czerni. Van Gogh, Picasso czy Wróblewski malowali noc i śmierć na niebiesko.

Na plakacie 16 widnieje w czerwonej poświacie młody żołnierz maszerujący z karabinem. Maszeruje z prawej do lewej strony obrazu, a zatem przychodzi nas bronić. Nawet współczesnemu widzowi nie kojarzy się z atakiem, tylko z obroną. Dlaczego? Jest to realistycznie ukazany bohater pozytywny. To tytułowy olbrzym. Obok widnieje groteskowy karykaturalny potworek - mały, pokraczny, wykrzywiony ludzik w czarnym stroju, monstrum przez zaburzenie proporcji i barw. Na szyi 
ma napis AK. W latach powojennych wszyscy znali pogardliwe sformułowanie używane przez komunistyczną propagandę: Armia Krajowa to tytułowy „zapluty karzeł reakcji”. Konstrukcja plastyczna obu plakatów, różnych tematycznie i kolorystycznie, jest identyczna. Na jednym z kilku plakatów głoszących slogan wyborczy „3 razy TAK" realistycznie ukazany jest robotnik, za nim czają się dwaj uzbrojeni mężczyźni z opaskami na ramionach (na jednej jest napis NSZ, na drugiej swastyka). Ci wrogowie ludu podpowiadają "3 razy NIE”. Postaci nakreślone są zgodnie z realizmem treści (realizm rodzajowy) i formy (realizm według norm obiektywnych). Niemniej jednak, tendencyjna kolorystyka postaci (robotnik w czerwonawej tonacji, żołnierz NSZ - białej, a hitlerowiec czarnej) wskazuje na posługiwanie się realizmem subiektywnym. Podobnie jak w kilku innych przypadkach, są tu też cechy groteski - postacie są schematyczne, o niedostatecznej determinacji cech. Plakat ten ma treść jawna, krótko scharakteryzowaną powyżej, widoczną dla każdego odbiorcy. Ma też treść ukryta, sugerowana, trafiającą do widza niejako bezrefleksyjnie, czyniąc z plakatu świetne narzędzie manipulacji. A mianowicie konotuje więź hitlerowca (wroga oczywistego) z żołnierzem armii podziemnej (wrogiem implikowanym). Jest to klasyczny mechanizm propagandowy „fałszywej koniunkcji” (Matuchniak-Krasuska 2010).

Plakaty realistyczne ukazują z reguły robotników przy pracy, a zatem "naszych”, „swoich”, „dobrych”, "potrzebnych” - można mnożyć podobne epitety. Dwóch dzielnych górników „wykona zadania 1955 ro$\mathrm{ku}^{\prime \prime}$, fedrując ofiarnie. Jest to realizm treści, poprzez ukazanie typowych górników (realizm rodzajowy), oraz realizm gestu, z uwagi na wyeksponowanie gestów - rąk dzierżących świder czy lampę. Są ukazani w sposób realistyczny - realizm formy według norm obiektywnych, choć jasną kolorystykę postaci, sugerującą ich pozytywny charakter, należy określić jako realizm subiektywny. Równocześnie jest to wymóg realistycznej kompozycji plastycznej: na czarnym, „węglowym” tle widnieje czerwona flaga (te kolory spełniają kryteria realizmu treści i formy), od której dobrze "odcinają się" szare sylwetki górników. Całość świetnie wpisuje się w konwencję realizmu socjalistycznego. „Bądź czujny” to realistyczny plakat ukazujący fragment twarzy robotnika, dokładnie, jak $\mathrm{z}$ fotografii. Jest tu połączenie realizmu treści (realizmu rodzajowego) z realizmem formy (iluzjonizmem). Warto zauważyć, że to samo przesłanie jest ukazywane poprzez różne rozwiązania plastyczne: realistyczne, 
jak w omawianym przypadku, czy groteskowe, jak na wyżej omówionym plakacie opatrzonym hasłem "strzeż tajemnicy...". Na pierwszym planie kolejnego plakatu stricte realistycznego dzielny robotnik z karabinem $\mathrm{w}$ ręku walczy o plan sześcioletni, chroniąc widoczne $\mathrm{w}$ tle traktory pracujące w polu.

Plakat "Dobry” kułak jest realistyczny, operuje realizmem rodzajowym (to „jakiś kułak") oraz realizmem gestu - charakterystyczna jest wielka pazerna dłoń wiejskiego bogacza, wielka z natury, a także potężna i groźna ideologicznie. Wyciągnięta $w$ stronę widza, grozi atakiem. Odbiorca czuje się zagrożony, choć nie ma tu ani broni, ani smoków. Postać jest zła, plakat ostrzega przed niebezpieczeństwem. Rzadko zły bohater jest ukazywany realistycznie, częściej groteskowo. Za groteskowe możemy uznać wielkie zęby wyszczerzone w fałszywym uśmiechu i niewidoczne oczy. Dokonujemy tu analizy tajemniczego uśmiechu, tylko że nie Mony Lizy, a kułaka.

Obok plakatów „ostrzegających" są też plakaty „zachęcające” do działania (te z górnikami i żołnierzem), ukazujące wzory pozytywne i podające instrukcje werbalne. Na kolejnym realistycznym, ale wesołym plakacie, czterech młodych ludzi kroczy $\mathrm{w}$ pochodzie $\mathrm{z}$ czerwonymi i zielonymi sztandarami, co konotuje sojusz robotniczo-chłopski środkami plastycznymi. Explicite wypisane hasła mają przyświecać bohaterom obrazu i widzom: „nie oddamy ziemi obszarnikom, nie oddamy fabryk i kopalń kapitalistom". Młody żołnierz w mundurze stoi na straży granic. To realizm treści (rodzajowy) i formy (według norm obiektywnych), wywołujący pełną aprobatę widza: dla treści, formy, emocji. Układając plakaty w sekwencję treściową, co zapewne czynili ich autorzy, zleceniodawcy, a potem i odbiorcy, można uznać, że młody żołnierz odwiedza swoich rodziców na wsi, sprawiając im ogromną radość, widoczną w gestach i słowach (napisanych). Najbardziej realistyczny, malarski jest plakat ukazujący wjazd czołgów do miasteczka, żołnierzy machających biało-czerwonymi i czerwonymi flagami, oraz ludność, która wybiegła na ich powitanie. „Żołnierz radziecki i polski przynieśli wolność naszej ojczyźnie" - głosi napis. Informacja jest radosna, zawiera same dobre słowa i sensy. Wypada wątpić, czy kolejność wymieniania żołnierzy jest przypadkowa. Przekaz plastyczny jest pogodny, optymistyczny. Warto zauważyć, że w wyżej omówionych przypadkach występuje zgodność między przekazem ikonicznym i werbalnym. W plakatach groteskowych częsty jest dysonans. 


\section{Podsumowanie: plakat jako przedmiot analiz socjologii sztuki}

$\mathrm{Z}$ analizy kilkudziesięciu plakatów, w dodatku tzw. wojennych, wynika podobieństwo treści, a różnorodność formy plastycznej. Wszystkie zarówno polskie, jak i niemieckie, rosyjskie, amerykańskie bądź hiszpańskie - zawierają treści informacyjne i pełnią funkcje perswazyjne. Wykorzystują natomiast, i to w każdej serii "narodowej”, wszystkie możliwe rozwiązania plastyczne - realizm, groteskę, abstrakcję.

Czysta abstrakcja na nich się nie pojawia, gdyż koliduje z funkcjami informacyjnymi. Występują natomiast kompozycje semi-abstrakcyjne, sugerujące wygląd postaci przedstawianych, oraz kompozycje zgeometryzowane. Ze zrozumiałych powodów są one nieliczne $-\mathrm{z}$ reguły po jednym plakacie w każdej serii. Warte jest to jednak odnotowania.

Wszystkie pozostałe, $\mathrm{w}$ dość równych proporcjach, stosują realistyczne lub groteskowe ujęcie postaci, niekiedy obydwa łącznie. Wykorzystanie tych konwencji można ująć lapidarnie - realizm dla swoich, groteska dla wrogów. To „wspólny mianownik” wszystkich plakatów. Występuje groteska satyryczna - karykatura (łącząca się z realizmem treści typu „Wierność indywidualna") oraz groteska fantastyczna (monstra skomponowane z elementów heteronomicznych). W każdym układzie zastosowana jest raczej perspektywa hierarchiczna - główny bohater w centrum, większy od innych. Pełni funkcje wzorcotwórcze, ułatwia identyfikację. Napis uzupełnia, uszczegóławia jego występ (w sensie Goffmanowskim). Informacja werbalna i wizualna są spójne. W plakatach "malarskich” uwzględniona jest także perspektywa geometryczna, renesansowa, utożsamiana przez odbiorców z realizmem. Często zastosowana jest przy tym kompozycja diagonalna, lepiej ukazująca ruch (atak na wroga lub atak wroga). Wyrazista forma ma silną funkcję perswazyjną.

Wszystkie plakaty wykorzystują dość ubogie zestawienia kolorystyczne. Niewątpliwie swoją rolę gra tu aspekt techniczny. Niemniej jednak paleta barw stosowana jest $\mathrm{w}$ sposób stereotypowy $\mathrm{z}$ uwagi na emocje wywoływane przez przekaz plastyczny - jasne kolory mają konotację pozytywną a ciemne - negatywną. Stosowane są więc odpowiednio do ukazywania "swoich” oraz „wrogów”, a także scen radosnych i scen cierpienia. Wątki podniosłe, patriotyczne malowane są za pomocą barw narodowych, nawet flag narodowych. Zawsze i wszędzie wykorzystywana jest czerwień, kolor najpiękniejszy i „najbardziej kolorowy”, mający różną konotację (barwy narodowe, krew, cierpienie, komunizm w sensie 
pozytywnym czy negatywnym). Ograniczenia kolorystyczne powoduja że z tego punktu widzenia jest mniej realizmu, a więcej konwencji. Można to zaliczyć do subiektywnego realizmu formy.

Na zakończenie wypada odkryć kulisy metodologiczne. Wbrew powszechnie przyjętym praktykom, autorka podsumowania nie czytała tekstów omawiających plakaty, nie starała się odczytać wszystkich napisów. Celem była analiza formy plastycznej plakatów pod kątem realizmu, groteski, abstrakcji, trzech typów sztuki. Plakat oddziałuje przede wszystkim formą plastyczna, ma być skuteczny także wobec odbiorcy niewykształconego, nawet analfabety. Jest percypowany pobieżnie, szybko, w ruchu, mimochodem. Starano się zatem odtworzyć sytuację odbiorcy wirtualnego. Na ile jest to poprawna interpretacja, to znaczy zgodna $\mathrm{z}$ intencjami nadawcy? Na ile jest nieadekwatna, w jakich przypadkach? Czy znajomość tekstu zmienia interpretację radykalnie?

Studium plakatów wojennych sytuuje się na pograniczu socjologii sztuki i socjologii polityki. Plakat należy zaliczyć do sfery polityki w aktualnej sytuacji wtedy, gdy powstaje i gdy jest eksponowany wobec rzeczywistej publiczności, odpowiadającej zresztą tej wirtualnej. Później trafia do sfery sztuki. Świadomi tej sytuacji są kolekcjonerzy, muzealnicy, badacze, o czym świadczy motto z jednej z wystaw: „Plakat jest trochę jak motyl, czasem bardzo piękny, czasem groźny, zazwyczaj budzący zainteresowanie. Jego żywot z reguły jest krótki i tylko dzięki kolekcjonerom potrafi po latach pokazać swe piękno oraz siłę oddziaływania" (Katalog wystawy 100 lat plakatu radzieckiego w Muzeum Historii Miasta Łodzi).

\section{Bibliografia}

Bourdieu, P., (1971), Le Marché des biens symboliques, „'L'Année Sociologique”, no 22.

Chwistek, L., (1961), Pisma logiczne i filozoficzne, t. 2. Warszawa: PWN.

Francastel, P., (1964), Problèmes de la sociologie de l'art, [w:] Traité de sociologie, t. 2, G. Gurvitch (red.). Paris.

Francastel, P., (1973), Twórczość malarska i społeczeństwo. Warszawa: PIW.

Fresnault-Deruelle, P., (1997), L'image placardée. Paris: Nathan.

Gryglewicz, T., (1984), Groteska w sztuce polskiej XX wieku. Kraków: Wydawnictwo Literackie.

Harpham, G., (1976), The Grotesque: First Principles, „Journal of Aesthetics and Art. Criticism".

Ingarden, R., (1966), Studia z estetyki, t. 2. Warszawa: PWN. 
Ingarden, R., (1970), Studia z estetyki, t. 3. Warszawa: PWN.

Kłoskowska, A., (1983), Socjologia kultury. Warszawa: PWN.

Kalinowski, W., (1973), Watki socjologiczne w polskiej estetyce międzywojennej. Wrocław: Wydawnictwo PAN.

Lascault, G., (1973), Le monstre dans l'art occidental. Un problème esthétique. Paris: Ed. Klincksieck.

Matuchniak-Krasuska, A., (1999), Publiczność wobec metafory plastycznej. O recepcji groteski Jerzego Dudy-Gracza. Łódź: Wydawnictwo Uniwersytetu Łódzkiego.

Matuchniak-Krasuska, A., (2010), Kategorie i reguty polskiego dyskursu o aborcji, [w:] Cudze problemy. O ważności tego, co nieważne. Analiza dyskursu publicznego w Polsce, M. Czyżewski, K. Dunin, A. Piotrowski (red.). Warszawa: Wydawnictwa Akademickie i Profesjonalne.

Możdżejko, E., (2001), Realizm socjalistyczny. Teoria, rozwój, upadek. Kraków: Universitas.

Ossowski, S., (1966), U podstaw estetyki. Warszawa: PWN.

Thomson, P., (1972), The Grotesque. London.

Wallis, M., (1968), Przeżycie i wartość. Kraków.

Zolberg, V., (1982), Constructing a Sociology of the Arts. Cambridge. 